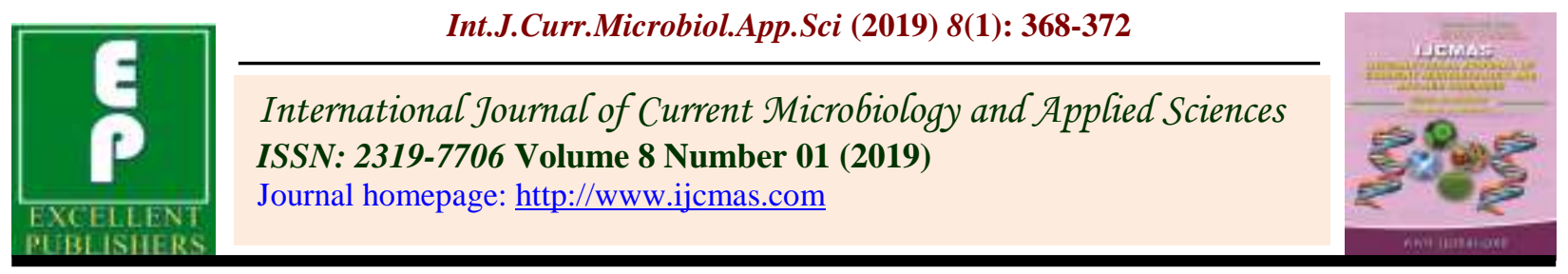

Original Research Article

https://doi.org/10.20546/ijcmas.2019.801.037

\title{
Effect of Fungicides and Neem Oil on the Rhizoctonia Root Rot of Soybean (Glycine max L.)
}

\author{
Anoop Kumar*, Sunil Zacharia, Amit Kumar Maurya and Vinny John \\ Department of Plant Protection, Sam Higginbottom Institute of Agriculture, Technology \& \\ Sciences, Allahabad (U.P.)-211007, India
}

*Corresponding author

\section{A B S T R A C T}

\section{Keywords}

Management, Neem oil, Rhizoctonia root rot, Soybean

Article Info

Accepted:

04 December 2018

Available Online:

10 January 2019
The efficacy of different fungicides (carbendazim, mancozeb, carboxin, thiophanate methyl, propiconazole) and neem oil were tested at100, 200 and 400 ppm in vitro and concentrations $2 \mathrm{~g} / \mathrm{kg}$ seed treatment and $2 \mathrm{ml} /$ lit. foliar spray against Rhizoctonia $\mathrm{sp}$., the causal organism of Rhizoctonia root rot of soybean in vivo. Among all the treatments, except neem oil showed $100 \%$ inhibition of radial growth of fungus in vitro. Seed treatment with carbendazim found to be most effective against Rhizoctonia root rot of soybean showing minimum disease incidence and producing maximum yield followed by mancozeb75 \% WP. It was observed thatcarbendazim50\% WP was statistically significant as compared to other treatments.

\section{Introduction}

Soybean [Glycine max (L.), Merrill] is known as "Golden Bean" of the $20^{\text {th }}$ century (Hymowitz and Harlan, 1983) and it is most important pulse as well as oil seed crop. It contains $20 \%$ oil and $40 \%$ high-quality protein. Soybean protein is rich in the valuable amino acid and lysine 5\% in which most of the cereals are deficient. It is one of the most important crops of the world cultivated over an area of 19.2 million ha $^{-1}$ with a production of 206.5 million tones. The area under soybean in India is 9.21 million $\mathrm{ha}^{-1}$ and production is 9.81 million tones along with yield of $1065 \mathrm{~kg} / \mathrm{ha}^{-1}$ (Anonymous, 2011). Rhizoctonia solani is a fungal pathogen that affects many agricultural plants. It is a soilborne fungus. It causes various plant diseases like collar-rot, root-rot and damping-off. Rhizoctonia bataticola (Pycnidial stage Macrophomina phaseolina) is the important soil-borne pathogen causes root rot/ charcoal rot disease in soybean. The infection is seen in seedlings and proves to be fatal in most cases. Damping-off is the most common seedling problem caused by the fungus that leads to death of the seedlings (Mehrotra, 1990). Rhizoctonia damage may occur at any time during the growing season, but it is more severe on young seedlings. Rhizoctonia solani can cause seed-rot, root-rot, and lesions on hypocotyls (Anne and Mills, 2010). 
Keeping in view, the above mentioned facts an investigation was undertaken to assess the efficiency of fungicides, and neem oil at different concentrations against Rhizoctonia $s p$.

\section{Materials and Methods}

The field experiment was conducted at SHIATS, Allahabad during kharif season of 2012 to observe the effect of mancozeb 75\% WP, propiconazole, carbendazim 50\% WP, thiophanate methyl, neem oil, and carboxinat different concentrations as compared to control in the form of seed treatment and foliar spray for the management of the Rhizoctonia root rot of soybean (Glycine max L.). The experiment was laid out in R.B.D. (Randomized Block Design) having seven treatments with three replications in a plot size of $2 \times 1 \mathrm{~m}^{2}$ and observations were recorded disease incidence and yield. The requisite quantity of seed was treated with fungicide before sowing in the field and treatments were sprayed thrice. The first spray was given as soon as symptoms of disease appeared. Second and third spray was given at 10 and 20 days after first spray. The experiment done using poisoned food technique on effect of radial growth $(\mathrm{mm})$ of Rhizoctonia solaniat different concentration (Each 100,200 and 400 ppm treatment was replicated three times invitro) (Nene and Thapliyal, 1979). The experiment was conducted in Completely Randomized Design.

\section{Results and Discussion}

Efficacy of different fungicides and neem oil on the growth of Rhizoctonia solani invitro

It was done by poisoned food technique. Perusal of data in Table 1 indicate that all the treatments mancozeb $75 \% \mathrm{WP}$, propiconazole, carbendazim 50\% WP, thiophanate methyl and carboxin were found highly effective while neem oil was less effective in managing the mycelial growth of Rhizoctonia solani.

Table.1 Effect of different treatments on the growth of $R$. solani at different concentrations due to poison food technique

\begin{tabular}{|l|c|c|c|}
\hline \multicolumn{1}{|c|}{ Treatments } & Concentration (ppm) & $\begin{array}{c}\text { Radial growth (Average } \\
\text { diameter) }\end{array}$ & \% inhibition over control \\
\hline Control & \multicolumn{2}{|c|}{} \\
\hline Mancozeb & - & $\mathbf{4 5 0 . 0 0}$ & 100 \\
& & 0.00 & 100 \\
& 100 & 0.00 & 100 \\
\hline Propiconazole & 200 & 0.00 & 100 \\
& 400 & 0.00 & 100 \\
& 100 & 0.00 & 100 \\
\hline Carbandazim & 200 & 0.00 & 100 \\
& 400 & 0.00 & 100 \\
\hline Thiophanate methyl & 100 & 0.00 & 100 \\
& 200 & 0.00 & 100 \\
\hline Neem oil & 400 & 0.00 & 100 \\
& 100 & 0.00 & 60.37 \\
& 200 & 22.33 & 94.82 \\
\hline Vitavax & 400 & 14.66 & 100 \\
& 100 & 2.33 & 100 \\
& 200 & 0.00 & 100 \\
\hline
\end{tabular}


Table.2 Effect of various treatments on disease incidence

\begin{tabular}{|c|c|c|c|}
\hline Treatment & $\mathbf{4 5}$ DAS & $\mathbf{6 0}$ DAS & $\mathbf{7 5}$ DAS \\
\hline Control & 20.00 & 32.666 & 49.33 \\
\hline Mancozeb & 10.0 & 15.333 & 25.33 \\
\hline Propiconazole & 17.33 & 24.666 & 32.66 \\
\hline Carbandazim & 6.66 & 11.333 & 22.66 \\
\hline thiophanate methyl & 18.00 & 25.333 & 34.66 \\
\hline Neem oil & 18.66 & 26.666 & 35.33 \\
\hline Vitavax & 10.66 & 16.000 & 28.0 \\
\hline
\end{tabular}

Table.3 Yield q/ha

\begin{tabular}{|c|c|c|c|c|}
\hline TREATMENTS & $R_{1}\left(q / h^{-1}\right)$ & $\mathbf{R}_{\mathbf{2}}\left(\mathbf{q} / \mathbf{h a}^{-1}\right)$ & $R_{3}\left(q / h^{-1}\right)$ & $\begin{array}{c}\text { Average } \\
\text { production }\left(\mathrm{q} / \mathrm{ha}^{-1}\right)\end{array}$ \\
\hline$T_{0}$ Control & 7.10 & 8.05 & 8.78 & 7.97 \\
\hline$T_{1}$ Dithane M-45 & 8.90 & 11.74 & 12.18 & 10.94 \\
\hline$T_{2}$ propiconazole & 8.14 & 8.30 & 11.08 & 9.17 \\
\hline $\mathbf{T}_{3}$ carbandazim & 10.28 & 11.23 & 11.54 & 11.21 \\
\hline $\mathbf{T}_{4}$ thiophenate Methyl & 8.50 & 9.27 & 10.40 & 9.36 \\
\hline$T_{5}$ Neem oil & 7.86 & 8.40 & 11.13 & 9.13 \\
\hline$T_{6}$ Vitavax & 9.40 & 10.32 & 11.30 & 10.34 \\
\hline
\end{tabular}

Similar findings have been observed by Kazmi et al.,(1995), Nasir et al., (2003), Singh and Varma (2005), Konde et al., (2008), Ray and Kumar (2008),Shovan et al., (2008), Mallesh et al., (2008), Ramesh et al., (2009) and EL-Habbaa et al., (2002) found Vitavax-T (25-200ppm) most effective against Rhizoctonia sp.

Efficacy of different fungicides and neem oil on the growth of $R$. solani causing root rot of Soybean in-vivo

The experiment was laid out in randomized block design (R.B.D.). All the treatments were found effective against Rhizoctonia root rot of soybean (Glycine $\max$ L.) in comparison to control. Seed treatment with mancozeb 75\% WP, carbendazim 50\% WP and carboxin $(2 \mathrm{gm} / \mathrm{kg}$ seed and foliar spray with propiconazole, thiophanate methyl, neem oil ( $2 \mathrm{ml} /$ lit.). Carbendazim found to be most effective against Rhizoctonia root rot of soybean (Glycine max L.) (Table 2) showing minimum disease intensity at 45, 60 and 75 DAS (6.66, 11.33 and $22.66 \%$ respectively) and producing maximum yield $(11.21 \mathrm{q} / \mathrm{ha})$ followed by mancozeb $75 \%$ WP minimum disease intensity at 45, 60 and 75 DAS (10.0, 15.33 and $25.33 \%$ respectively) and producing maximum yield (10.94 q/ha) as compared to $49.33 \%$ disease intensity and $7.97 \mathrm{~g} / \mathrm{ha}^{-1}$ yield in control (Table 3). It was observed that carbendazim 50\% WP was statistically 
significant as compared to other treatments. Among carbendazim 50\% WP was found best (Table 1) showing $22.66 \%$ disease intensity as compared to control. The results of the present study are in accordance to the findings of Abou-Zeid et al., (1987), Jatav and Mathur (2005), Ray et al., (2007), Konde et al., (2008), Niaz et al., (2008). Shovan et al (2008) reported the complete inhibition of radial growth of Colletotrichum dematium with Tilt-250EC Mallesh et al., (2009) found propiconazole most effective against Rhizoctonia sp. at all stages. and Andrabi et al., (2011)conducted an experiment under field conditions on the effect of fungicides and neem oil on the Rhizoctonia root rot of soybean (Glycine max L.) and reported that carbendazim 50\% WP was more effective@ $2 \mathrm{gm} / \mathrm{kg}$ seed treatment showing least disease intensity of $22.66 \%$ as against $49.33 \%$ in control. In the present studies, all the treatments tested statistically gave significant results against Rhizoctonia root rot of soybean (Glycine max L.).

\section{Acknowledgement}

The authors are grateful to Head, Department of Plant Protection for providing the necessary facilities to carry out the present research.

\section{References}

Abou-Zeid, N. M., Abada, K. A. and Ragab, M. M. 1987. Effect of different fungicides in vitro and in vivo on the control of soybean damping-off disease. Agricultural Research Review; 65: (2), 263-269.

Andrabi, M., Vaid, A. and Razdan, K. V. 2011. Evaluation of different measures to control wilt causing pathogens in chickpea. Journal Plant Protection Research; 51(1).

Anne. E., Dorrance and Mills, D. R. 2010.
Rhizoctonia Damping-off and stem rot of soybean. Department of Plant Pathology. The Ohio state University.

Anonymous 2011. All India area, production and yield of soybean along with coverage under irrigation, Directorate of economics and statistics Department of Agriculture and co- operation India.

El-Habbaa, Felaifel, G.M., Zahra M.S., Abdel-Ghany A.M., and R.E. 2002. Invitro evaluation of some fungicides commercial bio-control formulation and natural plant extracts on peanut root rot pathogens. Egyptian J. Agri. Res. 80(3): 1017-1030.

Hymowitz, T., and Harlan, J.R. 1983. Introduction of soybean to North America by Samuel Bowen in 1765 . Bot. 37: 371-379.

Jatav, R. S. and Mathur, K. 2005. Bio-agents and neem based seed treatment for management of root-rot complex in cluster bean. Indian Phytopathology; 58(2): 235-236.

Kazmi, S. A. R., Shahzad S. and Niaz I. 1995. Effect of neem oil on in-vitro growth of root infecting fungi. Pakistan J. Bot. 27(1): 217-220.

Konde, S. A., Raut, B.T. and Gade, M.R. 2008. Chemical and biological management of root rot (Rhizoctonia bataticola) of soybean. Annals Plant Physiology, 22(2): 275-277.

Mallesh, S.B. and Narendrappa, T. 2009. Management of root rot of sage, Salvia officinalis caused by Fusarium solani and Rhizoctonia solani. Indian Journal of Plant Protection; 37(1/2): 119-122.

Mehrotra, M. D. 1990. Rhizoctonia solani, a potentially dangerous pathogen of khasi pine and hardwoods in forest nurseries in India. European Journal Forest Pathology, 20(6-7): 329-338.

Nasir, N. 2003. Effect of fungicides in limiting the growth of seed borne fungi of soybean. Pakistan Journal of Plant 
Pathology, 2(2): 119-122.

Nene, Y.L. and Thapliyal, P.N. 1979. Fungicides in plant diseases control Oxford and IBM, IIIrd edition, New Delhi, 531-532 pp.

Niaz, I., Sitara, U., Kazmi, S. A. R., and Qadri S. 2008. Comparison of antifungal properties of neem seed oil collected from different parts of Pakistan. Pak. J. Bot., 40(1): 403-408.

Ramesh, K. R. 2009. Inhibition of Rhizoctonia solani the causal agent for collar rot of teak (Tectona grandis) seedlings by fungicides and bio-control agents in in-vitro conditions. Indian Forester, 126(3): 284-288.

Ray, A. and Kumar, P. 2008.Evaluation of fungicides against Rhizoctonia solani Kuhn, the incident of aerial blight of soybean. Pantnagar Journal Research, 6(1): 42-47.

Ray, A., Tripathi, P. and Kumar, H. S. 2007. Evaluation of bio-agents against
Rhizoctonia solani Kuhn the cause of aerial blight of soybean. Indian Phytopathology, 60(4): 532-534.

Shovan L. R., Bhuivan. M. K. A., Pegum, Z.A. and Pervez, Z. 2008. In-vitro control of Colletrotrichum dimatium causing Anthracnose of soyabean by fungicides, plant extracts and Trichoderma harzianum. International J. Sustain. Crop Prod., 3(3): 10-17.

Singh, G. and Varma, R. K. 2005. Compatibility of fungicides and neem products against Fusarium solani f. sp. glycines causing root rot of soybean and Trichoderma spp. Journal of Mycopathological Research, 43(2): 211-2140.

Syed, Ehteshamul-Haque and Ghaffar, A. 1995. Effect of Bradyrhizobium japonicum and fungicides in the control of root rot disease of soybean. Pakistan Journal of Botany, 27(1): 227-23.

\section{How to cite this article:}

Anoop Kumar, Sunil Zacharia, Amit Kumar Maurya and Vinny John. 2019. Effect of Fungicides and Neem Oil on the Rhizoctonia Root Rot of Soybean (Glycine max L.). Int.J.Curr.Microbiol.App.Sci. 8(01): 368-372. doi: https://doi.org/10.20546/ijcmas.2019.801.037 